Acta vet. scand. $1981,22,307-314$.

From the State Veterinary Serum Laboratory, Ringsted, Denmark.

\title{
THE SIGNIFICANCE OF NT1, NT2, AND NT3 ANTIGENS IN EPIDEMIOLOGICAL INVESTIGATIONS OF BOVINE GROUP-B STREPTOCOCCUS INFECTIONS
}

\author{
By \\ Niels Einar Jensen and Burghild Berg
}

JENSEN, NIELS EINAR and BURGHILD BERG: The significance of NT1, NT2 and NT3 antigens in epidemiological investigations of bovine group-B streptococcus infections. Acta vet. scand. 1981, 22, 307-314. - On typing of 90 strains of bovine Group-B streptococci (B-str.) from 21 herds, NT1, NT2 and NT3 antigens were found in $30 \%$, viz., NT1 in $14.4 \%$, NT2 in $3.3 \%$, and NT3 in $12.2 \%$. In 9 of the 21 herds examined $(43 \%)$ one or other of these antigens was found.

Among 8 strains from 4 herds of Herd type NT the NT1 antigen was demonstrated once.

In 5 herds of Herd type $X, 20$ strains were typed, and 9 isolates $(45 \%)$ from 3 herds $(60 \%)$ carried one or other of the three antigens.

Among herds in which the herd type was referable to polysaccharide antigens of the accepted set, NT3 antigen was present in 1 herd of Herd type Ia, namely along with IaX antigens in two strains, and with Ia antigen in one. In 3 herds of Herd type Ibc and in 2 herds of Herd type Ib no NT1, NT2, or NT3 antigen was demonstrated. On the other hand, such antigens were found in all of 4 herds of Herd type III, being present in $50 \%$ of the strains (14/28) examined, and the frequency of NT1, NT2, and NT3 antigens was only slightly higher among NT and $X$ strains $(10 / 19$ or $53 \%)$ than among III and IIIX strains $(4 / 9$ or $44 \%)$.

The NT2 reference strain carried the Ibc protein antigen. In addition to strong homologous reactions, NT1 antiserum reacted with B-str. group antigen, NT2 antiserum with Ibc antigen, and NT3 antiserum with the NT1 reference strain.

It is concluded that the NT1, NT2, and NT3 antigens are of doubtful value in epidemiological studies on bovine infections with group-B streptococci.

group-B streptococci; serological types; "new" NT - a n tigens.

The current serological typing scheme for group-B streptococci (B-str.), which comprises the polysaccharide antigens Ia, Ib, II and III, and the protein antigen Ibc, leaves some strains non-typeable. 
The number of such strains seems to vary with time and place (Perch et al. 1979). Evidently the source of the strains (Jensen 1980a, 1980b) and probably the typing method may have a significant influence on the percentage of non-typeable strains.

Among human urogenital B-str. isolates collected from November 1976 through September 1977 (Jensen 1980a) less than one percent (1/114) were deficient in polysaccharide (Ia, Ib, II, III) or protein (Ibc) antigens.

Perch et al. reported recently that some $10 \%$ of B-str. isolated from various sources in Denmark during the last 16 years were deficient in the above-mentioned antigens.

In recent years attempts have been made to reduce the number of non-typeable strains by including new polysaccharide antigens in the typing regimen (Wilkinson 1977, Perch et al.). Although in the USA non-typeable strains amount to less than $3 \%$ of human B-str. isolates a study was carried out (Wilkinson) to determine whether such strains possess as yet unrecognized type antigens. Of 8 non-typeable strains tested, only 1 (NT1) gave rise to type-specific antibodies against polysaccharide antigens. This antiserum reacted with only 5 of 53 nontypeable isolates tested, and Wilkinson therefore concluded that at present it would not be useful to include antiserum against NT1 in the battery of antisera used in epidemiological studies.

Perch et al. prepared antisera against 2 non-typeable strains named 12351 (NT2) and 7271 (NT3) and against Wilkinson's NT1 strain, and found that their strains gave rise to antibodies against type antigens appearing to be of polysaccharide nature. Among 78 non-typeable strains tested, $15(19.2 \%)$ could be classified as NT2, $2(2.6 \%)$ as NT3 and $3(3.8 \%)$ as NT1.

The majority of the Danish bovine B-str. strains examined were found to carry polysaccharide antigens and/or the Ibc protein antigen $(1112 / 1369,81 \%)$. Fourteen \% (192/1369) were typeable when the protein $X(190)$ and $R(2)$ antigens were included in the typing scheme (Jensen 1980b) and only $5 \%$ $(65 / 1369)$ possessed none of the recognized antigens of B-str. However, owing to extensive type variations among bovine strains of B-str., the majority of such strains $(57 / 65)$ could be referred to a herd type (Jensen 1980b, 1980d).

The present study was undertaken to estimate the prevalence of the NT1, NT2, and NT3 antigens among bovine B-str. strains. 
Special attention was paid to strains deficient in the officially recognized B-str. type antigens.

\section{MATERIAL AND METHODS}

The following definitions are used:

Herd type : denotes an antigen combination admitting of shifts between antigens included in the combination but not among these and any other antigens. The herd type is specified by a principal antigen (Jensen 1980b).

NT : B-str. strains deficient in the accepted polysaccharide (Ia, Ib, Iabc, II, and III) and protein (Ibc) antigens as well as in the protein $X$ and $R$ antigens.

NT1, NT2, : represent "new polysaccharide types", namely NT3 strains SS 1169 of Wilkinson, and strains 12351 and 7271 of Perch et al.*

The material includes $90 \mathrm{~B}$-str. strains isolated from cases of subclinical mastitis in the period April 1976 through March 1979. The strains originate from 21 herds and represent $39 \%(90 / 229)$ of the total of B-str. strains isolated from these herds during that period.

The strains were serologically typed by double diffusion in agarose gel (Jensen 1979). This method, which will reveal $\mathrm{Ia}, \mathrm{Ib}$, Ibc, Iabc, II, III, R, and X antigens, is based on the use of monospecific antisera and bacterial extracts of single-colony derivation.

When first examined the 90 strains were serologically typed as follows: NT: $19 ; \mathrm{X}: 31$; Ibc: 22 ; Ia: 2 ; IaX: 4 ; Ib: 3 ; III: 2 ; IIIX: 7. The following herd types were represented: Ia, Ib, III, Ibc, $X$, and NT. Since the first typing the strains had been kept in the lyophilized state.

Conventional serological typing of the NT1, NT2, and NT3 strains was performed by double diffusion in agarose gel. Same technique was applied when testing the corresponding antisera with respect to reactivity against the accepted set of B-str. antigens and the NT1, NT2, and NT3 antigens (Jensen 1979).

* Reference strains NT1, NT2, and NT3, and antisera against these strains, were kindly supplied by dr. phil. Beate Perch, Statens Seruminstitut, Copenhagen. 
The 90 strains selected were tested against unabsorbed antisera for NT1, NT2, and NT3. This was possible, since the typing method includes the use of reference controls, and because the reactions of the antisera were easy to interpret (see Results section). In the reference row, extracts of NT1, NT2, and NT3 were substituted for the $R, X$, and 090R extracts.

\section{RESULTS}

Typing of extracts of NT1, NT2, and NT3 against the conventionel test sera revealed that NT2 carried the Ibc protein antigen. No other recognized B-str. type antigens could be demonstrated.

When the NT1, NT2, and NT3 antisera were tested against the ordinary set of reference antigens plus the NT1, NT2, and NT3 extracts, strong homologous reactions were recorded. In addition, the NT1 antiserum was found to contain minor amounts of B-str. group antibodies. The NT2 antiserum con-

T a ble 1. Occurrence of NT1, NT2, and NT3 among 90 strains of Group-B streptococci of different herd-type origin.

\begin{tabular}{|c|c|c|c|c|c|c|c|c|}
\hline $\begin{array}{l}\text { Herd } \\
\text { type }\end{array}$ & $\begin{array}{c}\text { Number of } \\
\text { isolates, with } \\
\text { serotype } \\
\text { specified }\end{array}$ & $\begin{array}{l}\text { Number } \\
\text { of herds } \\
\text { examined }\end{array}$ & $\begin{array}{l}\text { Number of } \\
\text { quarters } \\
\text { examined }\end{array}$ & $\begin{array}{r}\mathrm{Nu} \\
\text { is } \\
\text { ca } \\
\mathrm{NT1}\end{array}$ & $\begin{array}{l}\text { Imber } \\
\text { solates } \\
\text { arrying } \\
\text { NT2 }\end{array}$ & $\begin{array}{l}\text { of } \\
\text { NT3 }\end{array}$ & $\begin{array}{c}\% \text { of } \\
\text { isolates } \\
\text { carrying } \\
\text { NT1, 2, or } 3\end{array}$ & $\begin{array}{l}\text { Number of } \\
\text { herds with } \\
\text { NT1, 2, or } 3\end{array}$ \\
\hline NT & $8 \mathrm{NT}$ & $4(4)^{\star}$ & $8(8)^{*}$ & - & 1 & - & 12.5 & 1 \\
\hline $\mathrm{X}$ & $\begin{array}{rl}1 & \mathrm{NT} \\
19 \mathrm{X}\end{array}$ & $5(5)$ & $20(46)$ & $\overline{2}$ & - & $\begin{array}{l}1 \\
4\end{array}$ & 45 & 3 \\
\hline Ibc & $\begin{aligned} 18 & \text { Ibc } \\
3 & \text { NT }\end{aligned}$ & $3(13)$ & $21(47)$ & - & - & - & 0 & 0 \\
\hline Ia & $\begin{array}{ll}4 & \mathrm{IaX} \\
2 & \mathrm{Ia}\end{array}$ & $3(6)$ & $6(14)$ & - & - & $\begin{array}{l}2 \\
1\end{array}$ & 50 & 0 \\
\hline Ib & $\begin{array}{ll}3 & \mathrm{Ib} \\
4 & \mathrm{Ibc} \\
2 & \mathrm{III}\end{array}$ & $2(8)$ & $7(12)$ & $\begin{array}{l}- \\
-\end{array}$ & - & - & 0 & 0 \\
\hline III & $\begin{array}{rl}7 & \text { IIIX } \\
12 & \mathrm{X} \\
7 & \mathrm{NT}\end{array}$ & $4(59)$ & $28(102)$ & $\begin{array}{l}2 \\
3 \\
6\end{array}$ & - & $\begin{array}{r}2 \\
1 \\
-\end{array}$ & 50 & 4 \\
\hline Total & 90 & $21(95)$ & $90(229)$ & 13 & 3 & 11 & & 9 \\
\hline
\end{tabular}


tained Ibc antibody (reacted with Ib and Ic extracts), while the NT3 antiserum gave a weak reaction with NT1 extract.

The results of the examination of the 90 strains for NT1, NT2, and NT3 antigens are given in Table 1. The herd types represented are listed in the first column, the more differentiated individual types in the second.

In herds of Herd type NT all of 8 strains were typed. NT2 was discovered in one strain. From herds of Herd type X, 20 strains, representing all of the 5 herds in question, were typed. Nine of these strains carried one or other of the NT-antigens. No such antigens could be demonstrated among 21 isolates from 3 herds of Herd type Ibc, or among 7 isolates from 2 herds of Herd type Ib. However, in 3 of 6 isolates from 3 herds of Herd type Ia, NT3 was present along with IaX (2 strains) or Ia (1 strain). In herds of Herd type III, NT1 and NT3 antigens were discovered rather frequently, namely in $30 \%(11 / 28)$ and $11 \%$ $(3 / 28)$ of strains, respectively. The frequency was slightly higher among NT and X strains (10/19 or $53 \%)$ than among III and IIIX strains $(4 / 9$ or $44 \%)$.

\section{DISCUSSION}

Perch et al. (1979) found NT1, NT2, or NT3 in $26 \%(20 / 78)$ of human non-typeable B-str. isolates. NT2 alone accounted for $19.2 \%(15 / 78)$, NT1 for $3.8 \%$ and NT3 for $2.6 \%$. Thirty \% of all bovine strains examined in the present study carried one or other of the NT-antigens. When comparing the two materials it must be remembered, however, that the present material includes strains typeable by other B-str. antigens. Forty strains had a polysaccharide or the Ibc protein antigen. Two of these strains carried the NT1 antigen and 5 the NT3 antigen $(7 / 40$ or $17.5 \%)$.

Among the 50 strains typeable by the $\mathrm{X}$ antigen (31) or referred to the NT category (19), $40 \%(20 / 50)$ reacted with NT1, NT2, and NT3 antisera, namely 12 strains with NT1, 2 strains with NT2, and 6 strains with NT3. The $40 \%$ positives should be compared with the $26 \%$ of Perch et al. The prevalence of NT1, NT2, and NT3 is different for the 2 materials.

Wilkinson (1977) and Perch et al. state that the NT1, NT2, and NT3 antigens are polysaccharides. Most other polysaccharide antigens of B-str., and the Ibc protein antigen as well, will give rise to protective antibodies (Lancefield et al. 1975). Whether 
this is the case with the NT1, NT2, and NT3 antigens is unknown, and so is therefore their relation to virulence.

A uniform antigenic structure of isolates from different quarters is to be expected within individual B-str. infected herds (Jensen 1980b). Differences between strains from the same herd can most often be ascribed to antigenic variation, and such "different" strains may usually be referred to a common herd type (Jensen 1980b, 1980c, 1980e, Jensen \& Berg 1980). The unanticipated sporadic appearance of NT1, NT2, and NT3 strains in $43 \%(9 / 21)$ of the herds examined is slightly disturbing and gives rise to the following questions:

1) Are the antigens NT1, NT2, and NT3 somehow related to well known B-str. antigens or to each other? The presence of Ibc antibody in NT2 antiserum and the fact that NT3 antiserum cross-reacted with NT1 antigen tend to confirm this suggestion.

2) Are these antigens subject to antigenic variation? Since most other B-str. antigens are (Jensen $1980 \mathrm{c}, 1980 \mathrm{e}$, Jensen \& Berg 1980) this might well be the case.

3) How often do these antigens occur by themselves, and how often do they co-exist with other antigens? The present material would seem to suggest a ratio of $40: 17.5$.

In this context it should be remembered that simultaneous occurrence of different polysaccharide antigens is seen occasionally in B-str. strains of both human (II/III, Ia/III) (Jelinkova 1977 ) and bovine (Ia/III) origin (Jensen 1980b). The Ia/III combination appears in few herds only (3/129), but in such herds most strains have the same antigen composition, unlike what in the case in herds in which NT1, NT2, and NT3 antigens occur.

\section{CONCLUSION}

On the basis of our present knowledge it is not possible to say what the antigens NT1, NT2, and NT3 may add to the epidemiological picture in bovine B-str. infections. Apparently these antigens emerge sporadically within certain epidemiological niches.

More information is needed about these antigens, especially about their possible variation and about their relation to virulence and to other antigens of B-str., before they can possibly be included in the typing system for B-str. 


\section{REFERENGES}

Jelinkova, J.: Group B streptococci in the human population. Current Topics in Microbiol. and Immunol. 1977, 76, 127-165.

Jensen, N. E.: Production and evaluation of antisera for serological type determination of group-B streptococci by double diffusion in agarose gel. Acta path. microbiol. scand. Sect. B 1979, 8\%, 77-83.

Jensen, N. E.: Serotypes of group-B streptococci in urogenital patients. Scand. J. infect. Dis. 1980a, 12, 101-104.

Jensen, N. E.: Distribution of serotypes of group-B streptococci in herds and cows within an area of Denmark. Acta vet. scand. 1980b, 21, 354-366.

Jensen, N. E.: Variation of type antigens of group-B streptococci. I. Variation of the $\mathrm{X}$-antigen and of other type antigens in herds where the X-antigen occurs. Acta vet. scand. 1980c, 21, 367374.

Jensen, $N$. E.: Herd types of group-B streptococci. The prevalence among herds in four Danish mastitis control districts and the relation of type to the spread within herds. Acta vet. scand. 1980d, 21, 633-639.

Jensen, N. E.: Variation of type antigens of group-B streptococci. III. Variation of the protein antigen Ibc. Acta vet. scand. 1980e, 21, $625-632$.

Jensen, N. E. \& B. Berg: Variation of type antigens of group-B streptococci. II. Studies on the in-vitro variation of the $X$-antigen and other type antigens. Acta vet. scand. 1980, 21, 617-624.

Lancefield, R. C., M. McCarty \& W. N. Everly: Multiple mouse-protective antibodies directed against group $B$ streptococci. J. exp. Med. 1975, 142, 165-179.

Perch, B., E. Kjems \& J. Henrichsen: New serotypes of group B streptococci isolated from human sources. J. clin. Microbiol. 1979, 10, $109-110$.

Wilkinson, $H$. W.: Nontypeable group B streptococci isolated from human sources. J. clin. Microbiol. 1977, 6, 183-184.

\section{SAMMENDRAG}

NT1, NT2 og NT3 antigenernes betydning ved epidemiologiske undersфgelser af gruppe B-streptokokinfektioner.

Ved serologisk typebestemmelse af 90 bovine grouppe B-streptokokstammer (B-str.) hidrørende fra 21 besætninger fandtes prævalensen af NT1, NT2 og NT3 antigenerne til $30 \%$ (NT1: 14,4\%, NT2: 3,3 \%, NT3: 12,2 \%). Det ene eller det andet af disse antigener påvistes i 9 af de 21 besætninger ( $43 \%$ ).

Blandt 4 besætninger af besætningstype NT påvistes NT1 antigenet $i$ eet tilfælde.

Blandt 20 stammer hidrørende fra 5 besætninger af besætnings- 
type X påvistes NT1, NT2 eller NT3 på 9 stammer (45 \%) med oprindelse i 3 af de unders $\varnothing$ gte besætninger.

Fra besætninger, hvor besætningstypen var baseret på forekomst af polysakkerid- eller Ibc proteinantigenet påvistes NT3 antigenet på 3 stammer i en besætning af besætningstype Ia ( 3 unders $\varnothing$ gte besætninger). NT1, NT2 eller NT3 påvistes derimod ikke blandt isolater fra 3 besætninger af besætningstype Ibc og 2 af besætningstype Ib.

Disse antigener påvistes i alle 4 unders $\varnothing$ gte besætninger af besætningstype III, og $50 \%$ af isolaterne (14/28) var positive. Inden for denne besætningskategori var der kun lille forskel $i$ frekvensen af NT1, NT2 og NT3 blandt NT og X stammer (10/19 eller $53 \%$ ) og III og IIIX stammer (4/9 eller $44 \%)$.

Referencestamme NT2 var i besiddelse af Ibc proteinantigenet. Foruden stærke homologe reaktioner reagerede antiserum NT1 med B-str. gruppeantigen, NT2 med proteinantigenet Ibc og NT3 antiserum med NT1 antigen.

Det konkluderes, at NT1, NT2 og NT3 antigenerne indtil videre må anses for at være af tvivlsom værdi ved epidemiologiske undersøgelser af bovine B-str. infektioner.

(Received February 12, 1981).

Reprints may be requested from: N. E. Jensen, the State Veterinary Serum Laboratory, Odinsvej, DK-4100 Ringsted, Denmark. 